\title{
Genetic Analysis of Variant Pilin Genes from Neisseria gonorrhoeae P9 Cloned in Escherichia coli: Physical and Immunological Properties of Encoded Pilins
}

\author{
By I. J. NICOLSON, ${ }^{1}$ A. C. F. PERRY, ${ }^{1}$ J. E. HECKELS ${ }^{2}$ AND \\ J. R. SAUNDERS ${ }^{1 *}$ \\ ${ }^{1}$ Department of Microbiology, University of Liverpool, PO Box 147, Liverpool L69 3BX, UK \\ ${ }^{2}$ Department of Microbiology, University of Southampton Medical School, Southampton General \\ Hospital, Southampton SO9 $4 X Y$, UK
}

(Received 27 June 1986)

\begin{abstract}
A series of genomic DNA fragments that encode gonococcal pilins from four well-characterized pilus variants of Neisseria gonorrhoeae strain P9 have been cloned in Escherichia coli K12. At least nine classes of cloned P9 pilin genes have been identified on the basis of restriction mapping of cloned pilin-encoding DNA and physical and immunological analysis of expressed pilin proteins. Each antigenic variant of strain P9 possesses many genomic segments of pilin gene information, although our results suggest that strain P9 contains only a single pilinexpressing ( pilE) locus.
\end{abstract}

\section{INTRODUCTION}

The pilus of Neisseria gonorrhoeae is a major adhesin and pathogenicity determinant that can vary antigenically within and between strains (Pearce \& Buchanan, 1978; Swanson, 1973). Pilus antigenic variation occurs both in vitro and in vivo (Lambden et al., 1980, 1981; Zak et al., 1984). Such variation in a major surface antigen may play a role both in the evasion of host defence mechanisms and in the sequential colonization of different tissue types during the course of an infection (Heckels, 1986).

The expression of pili by $N$. gonorrhoeae is subject to modulation by two distinct, but possibly related, genetic mechanisms: a phase variation in which piliated $\left(\mathrm{P}^{+}\right)$cells can become nonpiliated $\left(\mathrm{P}^{-}\right)$and vice versa, and antigenic variation, which results in alteration of the biochemical and immunological properties of pilin, the homopolymeric protein subunit of pili (Meyer et al., 1982; Saunders, 1986; Segal et al., 1985; Swanson et al., 1985). Production of pili by $N$. gonorrhoeae is dependent on the presence of at least one intact pilin-expressing ( pilE) locus within the gonococcal genome (Meyer et al., 1982, 1984; Swanson et al., 1985). N. gonorrhoeae MS11, the strain most frequently utilized for genetic studies on piliation, has given rise to several distinct evolutionary variants, including strain $\mathrm{MSl}_{\mathrm{ms}}$, whose genome contains two pilE copies (Meyer et al., 1984) and strain MS11 ${ }_{\mathrm{mk}}$, whose genome contains only a single pilE locus (Swanson et al., 1985). Phase variation from $\mathrm{P}^{+}$to $\mathrm{P}^{-}$may be effected by chromosomal rearrangements that give rise to deletions of all or part of a pilE locus (Segal et al., 1985; Swanson et al., 1985). In strains containing a single pilE gene, deletion of this locus will lead to an irreversible $\mathrm{P}^{+}$to $\mathrm{P}^{-}$ switch and the generation of non-reverting $\mathrm{P}^{-}$bacteria (Bergstrom et al., 1986; Swanson et al., 1985). However, in strains containing two pilE loci, the deleted gene can be repaired by recombination with the additional intact pilE copy (Segal et al., 1985). Further mechanisms, not requiring deletion of pilE and producing gonococci with reverting $\mathrm{P}^{-}$phenotypes, are also involved in piliation control (Bergstrom et al., 1986; Swanson et al., 1985).

Antigenic variation in gonococcal pili arises by alteration of the pilin-coding sequences at the pilE locus. Silent pilin sequences, representing fragments of the intact pilin gene, are widely 
distributed throughout the chromosome of $N$. gonorrhoeae MS11 ${ }_{\text {ms }}$ (Haas \& Meyer, 1986; Meyer et al., 1984). Data obtained from sequencing variant pilin-specific mRNA species support a model of pilus antigenic variation that operates by intragenic recombination at pilE loci, involving previously unexpressed pilin sequences (Hagblom et al., 1985).

Studies so far on the genetic mechanisms of antigenic variation in gonococcal pili have concentrated on $N$. gonorrhoeae strain MS11. However, the biochemical and immunological properties of variant pili produced by this strain have been poorly characterized. In contrast, four well-characterized isogenic variants of $N$. gonorrhoeae P9 (designated P9-2, P9-20, P9-35 and P9-37) have been isolated, each of which produces pili that are immunologically distinct from, but related to, those of the others (Lambden et al., 1981). In this paper we report the cloning of pilin-coding sequences from these variants of strain P9 and describe the physical and immunological properties of the pilins they encode.

\section{METHODS}

Bacterial strains and plasmids. The strains of $N$. gonorrhoeae used in this study have been described in detail elsewhere (Lambden et al., 1981). Preliminary analysis of cloned DNA was in Escherichia coli GCl (Meyer et al.,

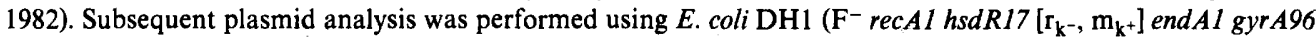
thi-1 supE44 $\lambda^{-}$) (Hanahan \& Meselson, 1980) as host. Plasmid pBR322 (Bolivar et al., 1977) was used as a cloning vector for the study of gonococcal genes in E. coli.

Reagents, enzymes and isotopes. All reagents were supplied by BDH unless stated otherwise. Ampicillin, tetracycline hydrochloride and bovine serum albumin (BSA) were supplied by Sigma. Tris was obtained from Boehringer Mannheim. Restriction endonucleases were obtained from Boehringer Mannheim, except for BamHI, EcoRI and HindIII, which were from P\&S Biochemicals, Liverpool, UK. Other enzymes used were nuclease BAL31 (P\&S Biochemicals), ribonuclease A (Sigma), and T4 DNA ligase, DNA polymerase I and calf intestinal alkaline phosphatase (Boehringer Mannheim). Reaction conditions for each enzyme were essentially as described by Maniatis et al. (1982). [ $\left.\alpha^{-32} \mathrm{P}\right] \mathrm{dATP}\left(3000 \mathrm{Ci} \mathrm{mmol}^{-1} ; 110 \mathrm{TBq} \mathrm{mmol}^{-1}\right)$ and ${ }^{125} \mathrm{I}$-labelled Staphylococcus aureus protein $\mathrm{A}\left(>30 \mathrm{mCi} \mathrm{mg}^{-1} ;>1 \cdot 1 \mathrm{GBq} \mathrm{mg}^{-1}\right)$ were supplied by Amersham.

Media and culture conditions. E. coli was grown at $37^{\circ} \mathrm{C}$ in $2.5 \%$ (w/v) nutrient broth (Lab M no. 2, London Analytical \& Bacteriological Media) solidified where necessary by the addition of agar to $1 \cdot 2 \%(\mathrm{w} / \mathrm{v})$. Where appropriate, liquid and solid media contained ampicillin $\left(100 \mu \mathrm{g} \mathrm{ml}^{-1}\right)$ or tetracycline hydrochloride (12.5 $\left.\mu \mathrm{g} \mathrm{ml}^{-1}\right)$.

N. gonorrhoeae $\mathrm{P} 9$ was grown for $18 \mathrm{~h}$ at $37^{\circ} \mathrm{C}$ in the presence of $7 \%(\mathrm{v} / \mathrm{v}) \mathrm{CO}_{2}$ on CTA medium, comprising $1.125 \%$ (w/v) Proteose Peptone no. 3 (Difco); $1 \%$ (w/v) nutrient agar (Lab M no. 2); 0.1\% (w/v) $\mathrm{KH}_{2} \mathrm{PO}_{4} ; 0.4 \%$ (w/v) $\mathrm{K}_{2} \mathrm{HPO}_{4} ; 0.5 \%(\mathrm{w} / \mathrm{v}) \mathrm{NaCl} ; 0.1 \%$ (w/v) soluble starch; and $1 \%(\mathrm{v} / \mathrm{v})$ of a solution containing $40 \%(\mathrm{w} / \mathrm{v})$ glucose, $0.5 \%(\mathrm{w} / \mathrm{v}) \mathrm{L}$-glutamine, $0.05 \%(\mathrm{w} / \mathrm{v}) \mathrm{Fe}\left(\mathrm{NO}_{3}\right)_{3}$ and $0.002 \%(\mathrm{w} / \mathrm{v})$ thiamin pyrophosphate.

DNA isolation and cloning procedures. Large-scale plasmid isolation was from chloramphenicol-amplified cultures of $E$. coli by the method of Humphreys et al. (1975). Small-scale plasmid isolation was by the method of Close \& Rodriguez (1982). N. gonorrhoeae P9 total DNA was isolated by the method of Stern et al. (1984) from bacterial lawns derived from single colonies. The predominance of piliated $\left(\mathbf{P}^{+}\right) \mathbf{P} 9$ cells in lawns was confirmed by electron microscopy.

Cloning procedures were essentially as described by Maniatis $e t$ al. (1982). To construct representative gene libraries, total DNA from each P9 variant was partially digested with combinations of either EcoRI and Sau3AI, or EcoRI and ClaI. Approximately $2 \mu \mathrm{g}$ of the resulting DNA fragments were then ligated to $1 \mu \mathrm{g}$ of the purified large fragment of $\mathrm{pBR} 322$ possessing suitable acceptor sites. In addition, a gene library of P9-35 was constructed by the ligation of $2 \mu \mathrm{g}$ P9-35 total DNA, cleaved to completion by ClaI, with $1 \mu \mathrm{g}$ of ClaI-linearized pBR322 DNA that had subsequently been treated with alkaline phosphatase $(100-300 \mathrm{ng})$. Each ligation mix was used to transform E. coli $\mathrm{GCl}$ to ampicillin resistance by the method of Brown et al. (1979) prior to immunological screening. Subsequent plasmid analyses and subcloning procedures were carried out using $E$. coli $\mathrm{DH} 1$ as host.

Monoclonal antibodies. The production of monoclonal antibodies reacting with gonococcal pili has been described previously (Virji \& Heckels, 1983; Virji et al., 1983). Antibody SM1 recognizes a conserved epitope on all pili from all strains tested to date; antibodies SM3, SM5, SM6 and SM13 recognize epitopes responsible for antigenic differences between pili from variants of strain P9.

Immunological screening. At least 10000 ampicillin-resistant colonies from each transformation were replicaplated on to nitrocellulose filters (Schleicher \& Schull BA85) at a density of 500-1000 colonies per $85 \mathrm{~mm}$ plate. Replica colonies were then screened for the production of SM1-reactive pilin, essentially by the method of Helfman et al. (1984). Monoclonal antibody SMI was diluted 1:2000 in TSA buffer $(0.02 \mathrm{M}-\mathrm{Tris} / \mathrm{HCl}, \mathrm{pH} 7.6$; $0.87 \%, \mathrm{NaCl} ; 0.05 \% \mathrm{NaN}_{3} ; 5 \mathrm{mg} \mathrm{BSA} \mathrm{ml}^{-1}$ ). ${ }^{125}$ I-labelled protein A was diluted in TSA to a specific activity of $10 \mathrm{nCi} \mathrm{ml}^{-1}$. 
Dot blotting. Bacterial suspensions $\left(2 \mu \mathrm{l}\right.$ of $\left.>10^{8} \mathrm{cells} \mathrm{ml}^{-1}\right)$ were applied to sheets of nitrocellulose, allowed to dry and lysed by exposure to $\mathrm{CHCl}_{3}$ vapour. Excess protein binding was blocked with $\mathrm{BSA}$ and the sheets were reacted with monoclonal antibody, washed and reacted with ${ }^{125} \mathrm{I}$-labelled protein $\mathrm{A}$ as previously described (Virji \& Heckels, 1983). Immunological reactivity was detected after overnight autoradiography.

Immunoblotting. Western blotting was performed after subjecting $25 \mu \mathrm{g}$ total cell protein per track to electrophoresis on a $12 \cdot 5-17 \cdot 5 \%(\mathrm{w} / \mathrm{v})$ linear gradient polyacrylamide gel. Proteins were transferred from the slab gel onto a nitrocellulose filter by electroblotting (Towbin et al., 1979). After incubation in BSA binding solution $(3 \%$, w/v, BSA; $150 \mathrm{mM}-\mathrm{NaCl} ; 50 \mathrm{mM}-\mathrm{Tris} / \mathrm{HCl}, \mathrm{pH} 7.5)$ to block non-specific binding sites, filters were soaked for $18 \mathrm{~h}$ in monoclonal antibody SM1 or rabbit anti-P9 pilus polyclonal antibody, diluted in TSA $1: 2000$ and $1: 200$ respectively. The filters were then washed five times with Tris/saline solution $(150 \mathrm{mM}-\mathrm{NaCl} ; 50 \mathrm{~mm}-\mathrm{Tris} / \mathrm{HCl}$, pH 7.5) and incubated for $18 \mathrm{~h}$ in ${ }^{125} \mathrm{I}$-labelled protein $\mathrm{A}\left(10 \mathrm{nCi} \mathrm{ml}^{-1}\right.$ in TSA). Each filter was then washed five times with Tris/saline solution prior to autoradiography.

Southern hybridizations. After electrophoresis, DNA was transferred to nitrocellulose filters by the method of Southern (1975). DNA-DNA hybridizations were performed under conditions of high stringency at $42^{\circ} \mathrm{C}$ in the presence of $50 \%(\mathrm{v} / \mathrm{v})$ formamide as described by Maniatis et al. (1982). Probes were labelled to a specific activity of approximately $5 \times 10^{8}$ d.p.m. $\mu \mathrm{g}^{-1}$ using the Polymeraid-RH random hexanucleotide priming system (P\&S Biochemicals).

\section{RESULTS}

\section{Genetic analysis of cloned pilin genes}

Plasmid gene libraries constructed using DNA isolated from each of four isogenic variants of $N$. gonorrhoeae P9 yielded a total of 85 SM1-reactive clones. Plasmid DNA preparations from clones eliciting SM1-reactive pilin were mapped using restriction enzymes (Fig. 1). All the pilinencoding plasmids possessed a unique $X b a I$ site, located at one terminus of a $1.6 \mathrm{~kb} E c o \mathrm{RI}-X b a \mathrm{I}$ fragment of gonococcal origin (Fig. 1). Restriction maps of some clones can be completely matched with those of others to produce classes of totally alignable restriction maps. On this basis, six different classes of restriction map have been found. All clones generated by the ligation of EcoRI-ClaI fragments of gonococcal DNA possess at least one small SmaI-ClaI segment. The absence of similar segments in some clones containing an EcoRI-Sau3AI gonococcal insert probably reflects the cloning strategy employed.

Subclones were constructed from pLV260 in order to localize the coding region for the structural pilin gene (Fig. 2). Further structural analysis by BAL-31 deletion about the unique $X b a I$ site in pLV260 indicated that the recombinant possesses a single expressed pilin gene, the boundary of which lies approximately $0.5 \mathrm{~kb}$ to one side of the $X b a \mathrm{I}$ site (data not shown). Approximately $1 \cdot 1 \mathrm{~kb}$ of the gonococcal insert of pLV260, containing all but $1 \mathrm{bp}$ of the Cterminal sequence of the pilin gene (data not shown) and capable of eliciting SM1-reactive pilin, was used to probe total DNA derived from P9 variants that had been digested to completion with ClaI endonuclease (Fig. 3). P9 total DNA that had been subjected to Southern analysis in this way possessed one of three distinguishable hybridization patterns comprising at least seven bands. With the exception of a faintly hybridizing $2.3 \mathrm{~kb}$ ClaI fragment that was generated on cleavage of P9-37 DNA, total DNA preparations from P9-2, P9-35, and P9-37 yielded apparently identical hybridization patterns. In each case, a $3.8 \mathrm{~kb}$ ClaI fragment was present that disappeared on cleavage with $\mathrm{XbaI}$ (Fig. 3). A fragment of similar size was also represented in the P9-20 hybridization pattern. This fragment presumably harbours all, or part of, the intact pilin coding sequence of each strain, since:

(i) All pilin-producing clones possess all, or presumably part, of a $3.8 \mathrm{~kb} \mathrm{ClaI} \mathrm{fragment.}$

(ii) All pilin-producing clones possess a single $\mathrm{XbaI}$ site, and digestion with $\mathrm{ClaI}$ and $\mathrm{XbaI}$ of plasmid DNA from clones possessing a $3.8 \mathrm{~kb}$ ClaI fragment results in the replacement of this fragment by two fragments, of 2.5 and $1.3 \mathrm{~kb}$. Fragments of similar size are represented in hydridization patterns of all P9 total DNA preparations that have been digested with ClaI and $X b a I$.

(iii) No other ClaI fragment represented is conserved in all hybridization patterns that is also digested with $\mathrm{XbaI}$.

(iv) P9-35 total DNA that had been digested to completion with ClaI was used to construct a gene library that yielded 16 pilin-producing clones. Eight of these were selected at random for 


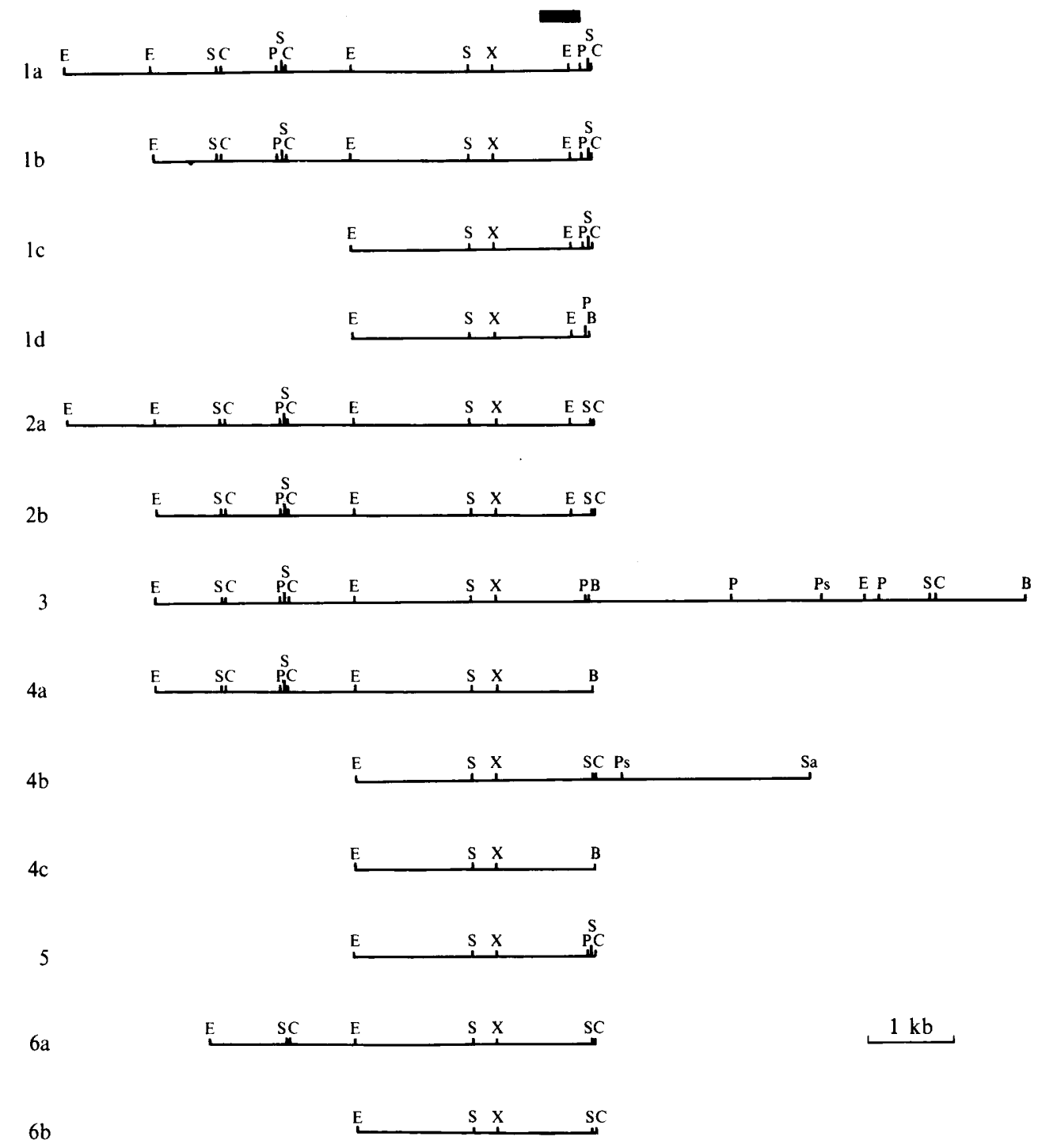

Fig. 1. Restriction analysis of DNA inserts derived from antigenic variants of $N$. gonorrhoeae strain P9 in recombinant pilin-producing plasmids. Restriction maps are aligned about a shared $E c o$ RI-XbaI fragment of $1.6 \mathrm{~kb}$. Numbers refer to classes of totally alignable restriction maps (see also Table 2). The position of the pilin gene of pLV260 is represented by a thickened bar (see text). Restriction sites: B, BamHI; C, ClaI; E, EcoRI; P, PvuII; Ps, PstI; S, SmaI; Sa, Sau3AI; X, XbaI.

restriction mapping, and all were found to contain a single gonococcal ClaI DNA fragment of $3.8 \mathrm{~kb}$ (Fig. 1 and data not shown).

(v) The hybridization pattern of a $\mathrm{P}^{-}$isogenic variant of P9-2 whose total DNA had been completely digested with ClaI lacked a band corresponding to a fragment of $3.8 \mathrm{~kb}$ (Fig. 3 ).

The respective hybridization patterns obtained for P9-20 DNA digested to completion with EcoRI, PstI, and PvuII (data not shown) and ClaI were markedly different from those obtained for P9-2, P9-35 and P9-37 DNAs (Fig. 3). However, using pilin gene sequences as probes, substantial differences have also been revealed between the Southern blotting patterns of sibling pilus variants of MS11, another strain of $N$. gonorrhoeae (Swanson et al., 1985). 

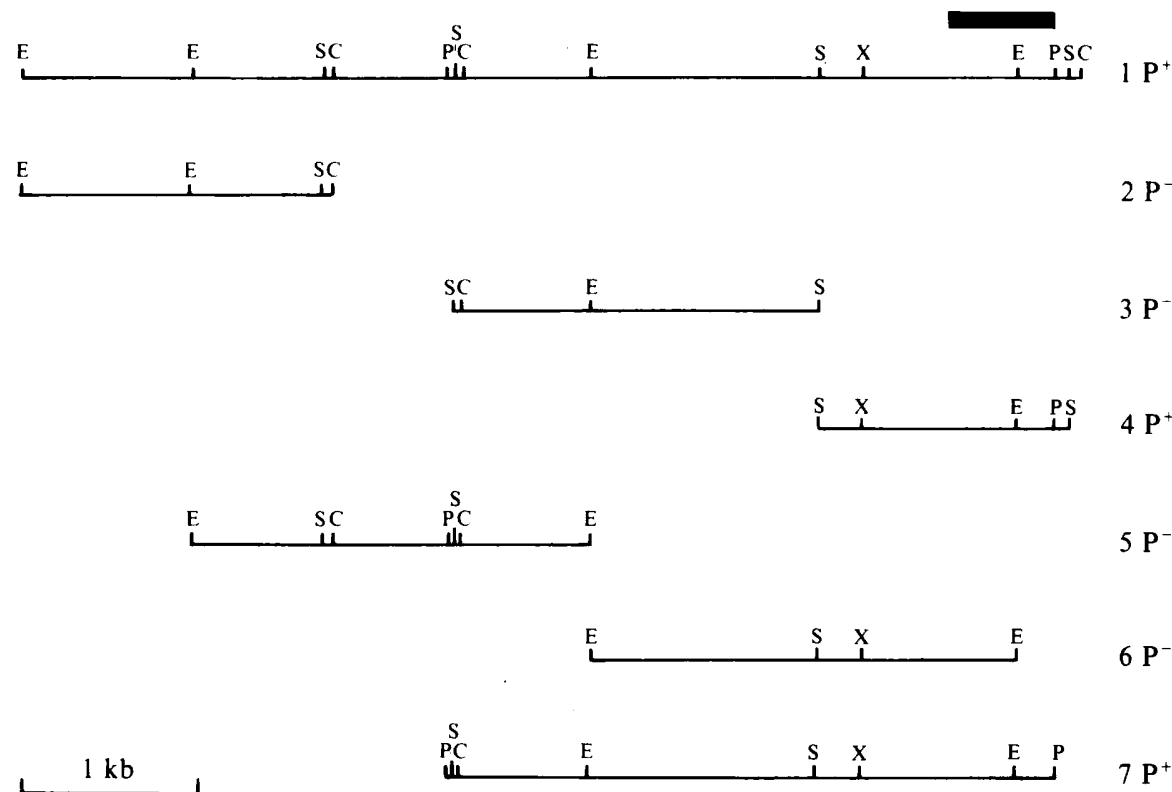

Fig. 2. Restriction maps of gonococcal inserts in subclones of pLV260, a recombinant, pilin-producing plasmid derived from P9-2. Sub-clones encoding SM1-reactive pilin are marked $\mathrm{P}^{+}$. The position of the pilin gene of pLV260 is represented by a thickened bar (see text). Restriction sites are abbreviated as in Fig. 1.

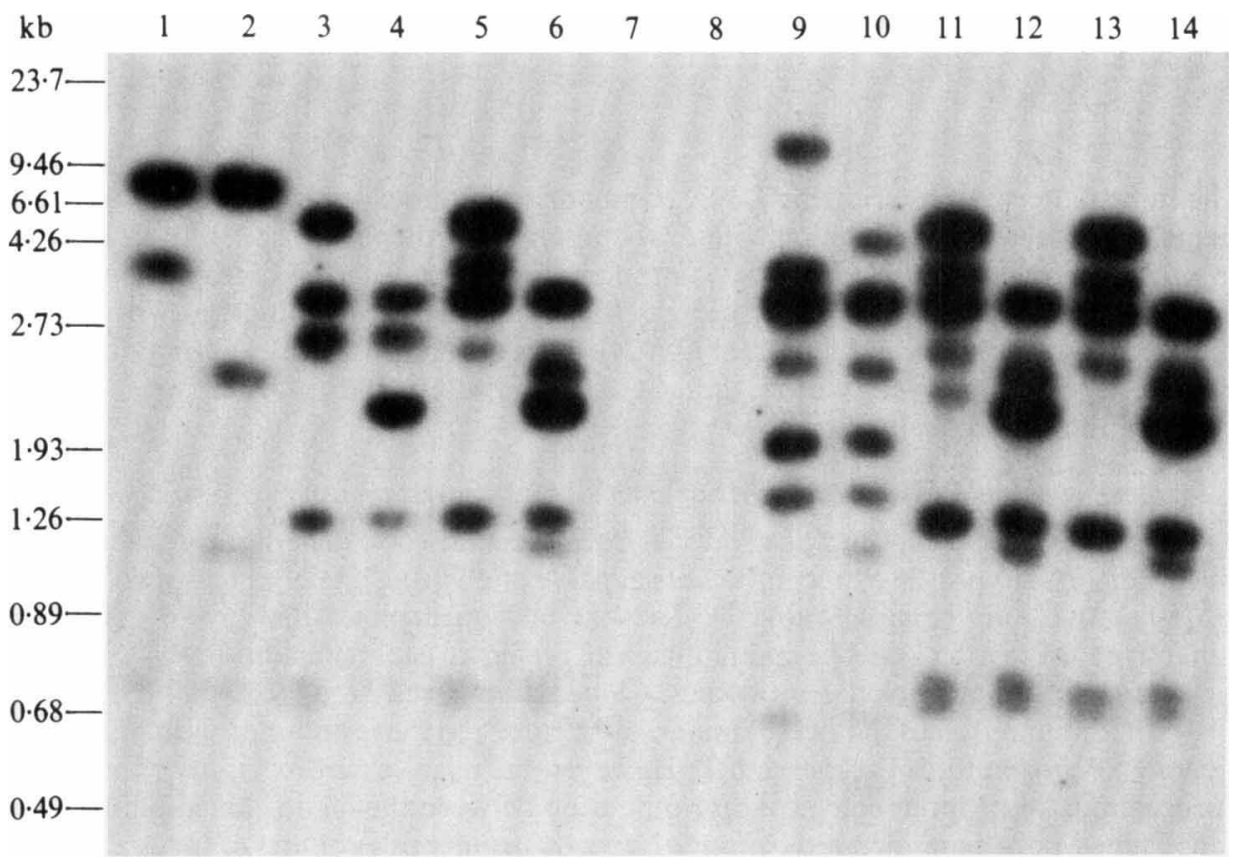

Fig. 3. Southern hybridization analysis of total DNA from antigenic variants of $N$. gonorrhoeae strain P9, using the $1.1 \mathrm{~kb} \mathrm{XbaI-PvuII} \mathrm{fragment} \mathrm{of} \mathrm{pLV260} \mathrm{as} \mathrm{probe.} \mathrm{Lanes:} \mathrm{1,} \mathrm{pLV260} \mathrm{DNA} \mathrm{digested} \mathrm{with}$ ClaI; 2, pLV260 DNA digested with ClaI + XbaI ; 3, P9-2 (P- derivative) DNA digested with ClaI; 4, P9-2 ( $\mathrm{P}^{-}$derivative) DNA digested with $C l a \mathrm{I}+\mathrm{XbaI}$; 5, P9-2 DNA digested with ClaI ; 6, P9-2 DNA digested with $C l a I+X b a I$; 7, SPP1 DNA digested with EcoRI; 8, $\lambda$ DNA digested with HindIII ; 9, P920 DNA digested with $C l a \mathrm{I} ; 10$, P9-20 DNA digested with ClaI + XbaI ; 11, P9-35 DNA digested with ClaI ; 12, P9-35 DNA digested with ClaI + XbaI ; 13, P9-37 DNA digested with ClaI ; 14, P9-37 DNA digested with $C l a \mathrm{I}+X b a \mathrm{I}$. 


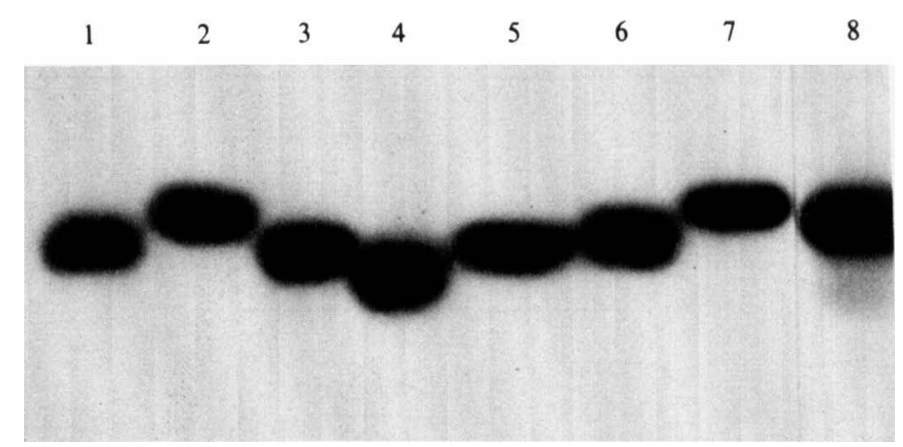

Fig. 4. Western blot analysis, using polyclonal antibody raised against whole $\mathrm{P} 9$ pili, of total protein in recombinant $E$. coli clones expressing gonococcal pilin(s). Clones representative of each size class of pilin derived from the four P9 variants are shown. Lanes: 1, DH1(pLV260); 2, DH1(pLV270); 3, DHl(pLV300); 4, DHl(pLV310); 5, DH1(pLV390); 6, DH1(pLV360); 7, DH1(pLV370); 8, DH1(pLV480).

Table 1. Reactivities of parental $N$. gonorrhoeae P9 variants with anti-pilus monoclonal antibodies (MAbs)

N. gonorrhoeae $\mathrm{P9}$
variant
P9-2
P9-20
P9-35
P9-37

$\begin{array}{ccccc}\text { MAb reactivities } \\ \text { SM1 } & \text { SM3 } & \text { SM5 } & \text { SM6 } & \text { SM13 } \\ + & + & + & - & + \\ + & - & - & - & - \\ + & - & - & + & + \\ + & - & - & + & -\end{array}$

The same patterns of hybridizing DNA fragments were observed when total DNA from P9 variants was digested to completion with $C l a \mathrm{I}$ and probed with either the $1 \cdot 1 \mathrm{~kb} X b a \mathrm{I}-P v u \mathrm{II}$ or the $1 \mathrm{~kb}$ EcoRI fragment of pLV260 (data not shown). Southern analysis of restriction fragments of pLV260 using pLV270 as probe suggests that pLV270 shares homology with sequences distributed along the gonococcal insert of pLV260 (data not shown). These findings indicate that DNA sequences conserved within and between pLV260 and pLV270 are represented throughout the gonococcal genome.

\section{Immunological and physical analysis of cloned pilins and relationship to restriction maps}

Analysis by Western blotting of all clones revealed that each gene library (excluding that derived from P9-20) possessed recombinants capable of eliciting one of at least two size classes of SM1-reactive pilin (Fig. 4, Table 2). The size of cloned pilin differs from that of its P9 originator by up to $1.5 \mathrm{kDa}$. The immunological profile of each cloned pilin was determined using a panel of five monoclonal antibodies. Cloned pilin genes from P9-20 and P9-37 encoded pilins with immunoprofiles that were similar, or identical, to those obtained with pili from their respective $\mathrm{P} 9$ progenitors (Tables 1 and 2). However, the relative non-reactivity of both types of gonococcal pili limits immunological discrimination between them and cloned pilins of shared origin. Cloned pilin genes derived from P9-2 encode polypeptides of one of two sizes. Pilins in one size class possess an immunoprofile distinct from those in the other, reacting either with monoclonal antibody SM3 or SM5, both of which are regarded as specific for pili from P9-2 (Tables 1 and 2; Virji \& Heckels, 1983). Superimposition of both immunoprofiles results in a spectrum of antibody reactivity indistinguishable from that produced by pili from $N$. gonorrhoeae P9-2 (Table 1). Generally pilins encoded in E. coli by cloned gonococcal genes were therefore apparently identical to pilins expressed by the source strain of $N$. gonorrhoeae P9. 
Table 2. Physical and immunological properties of cloned pilins and relationship to restriction maps

\begin{tabular}{|c|c|c|c|c|c|c|c|c|}
\hline \multirow{2}{*}{$\begin{array}{l}\text { Class of } \\
\text { restriction } \\
\text { map }\end{array}$} & \multirow{2}{*}{$\begin{array}{l}\text { Recombinant } \\
\text { plasmid(s) }\end{array}$} & \multirow{2}{*}{$\begin{array}{l}\text { N. gonorrhoeae } \\
\text { P9 originator }\end{array}$} & \multirow{2}{*}{$\begin{array}{c}\text { Apparent } \\
\text { mol. mass } \\
\text { of pilin } \\
(\mathrm{kDa})\end{array}$} & \multicolumn{5}{|c|}{ MAb reactivities } \\
\hline & & & & SMI & SM3 & SM5 & SM6 & SM13 \\
\hline la & pLV250, pLV260 & P9-2 & $19 \cdot 0$ & + & + & - & - & + \\
\hline 1a & $\begin{array}{l}\text { pLV370, pLV380 } \\
\text { pLV493 }\end{array}$ & P9-35 & $20 \cdot 5$ & + & - & - & + & + \\
\hline $1 b$ & pLV400 & P9-35 & $20 \cdot 5$ & + & - & - & + & + \\
\hline $1 b$ & pLV460 & P9-35 & 20.5 & + & - & - & + & + \\
\hline lc & pLV320 & P9-2 & $20 \cdot 0$ & + & - & + & - & + \\
\hline lc & pLV430, pLV440 & P9-35 & $20 \cdot 5$ & + & - & - & + & + \\
\hline lc & pLV350, pLV450 & P9-35 & $20 \cdot 5$ & + & - & + & - & + \\
\hline lc & pLV340 & P9-35 & $20 \cdot 5$ & + & - & - & + & + \\
\hline ld & pLV270 & P9-2 & $20 \cdot 0$ & + & - & + & - & + \\
\hline $2 a$ & $\begin{array}{l}\text { pLV410, pLV420 } \\
\text { pLV490, pLV491 }\end{array}$ & $\mathrm{P} 9-35$ & $20 \cdot 5$ & + & - & - & - & + \\
\hline $2 \mathrm{~b}$ & pLV360 & P9-35 & $19 \cdot 5$ & + & - & - & - & + \\
\hline 3 & pLV300 & P9-37 & $19 \cdot 0$ & + & - & - & - & - \\
\hline $4 a$ & pLV290 & P9-37 & 18.5 & + & - & - & - & - \\
\hline $4 b$ & pLV310 & P9-37 & 18.5 & + & - & - & - & - \\
\hline $4 c$ & pLV280, pLV281 & P9-37 & $18 \cdot 5$ & + & - & - & - & - \\
\hline 5 & pLV390, pLV492 & P9-35 & $19 \cdot 0$ & + & - & - & - & - \\
\hline $6 a$ & $\begin{array}{l}\text { pLV480, pLV483 } \\
\text { pLV486, pLV487 }\end{array}$ & P9-20 & $19 \cdot 5$ & + & - & - & - & - \\
\hline $6 \mathrm{~b}$ & $\begin{array}{l}\text { pLV481, pLV484 } \\
\text { pLV485 }\end{array}$ & P9-20 & $19 \cdot 5$ & + & - & - & - & - \\
\hline
\end{tabular}

However, several cloned pilins possessed immunological profiles distinct from those of the P9 strain from which they were obtained and/or from those of any other clones (Table 2).

Restriction data on pilin-producing recombinant plasmids can be combined with physical and immunological characteristics of the pilin(s) elaborated by each, to identify at least nine classes of cloned gonococcal pilin (Table 2, Fig. 4). All recombinant plasmids that possess a $0.6 \mathrm{~kb} E c o \mathrm{RI}-X b a \mathrm{I}$ fragment encode SM13-reactive pilin(s). The EcoRI site at the terminus of the analogous fragment of pLV260 bisects the pilin gene in that recombinant, and may therefore define the coding region for the SM13-reactive epitope.

\section{DISCUSSION}

We have cloned in $E$. coli a series of pilin genes from four well-characterized pilus antigenic variants of $N$. gonorrhoeae P9. Restriction maps of the gonococcal sequences in variant pilinproducing recombinant plasmids can all be aligned on one side of the unique $X b a I$ site present in each, whilst exhibiting differences on the other side that render them non-alignable. Since the pilin-coding sequence of pLV260 lies on the side of its $X b a I$ site that is non-alignable, differences among clones between restriction maps of analogous segments may, therefore, reflect changes at the DNA level that are ultimately responsible for antigenic variation. Similarities between the restriction maps of recombinants, in conjunction with Southern hybridization analyses of genomic DNA from P9 variants using pilin gene sequences as probes, indicate that each variant possesses only a single expressed copy of the intact pilin gene. In this respect, strain P9 resembles MS1 $1_{\mathrm{mk}}$, which has been shown to possess one pilE locus (Swanson et al., 1985), but is unlike strain MS1 $1_{\mathrm{ms}}$, which possesses two such loci (Meyer et al., 1984).

The generation by $N$. gonorrhoeae of pilus variants with antigenically distinct pili has been explained by a cassette model of gene conversion (Segal et al., 1986). According to this model, novel pilin genes are assembled at a pilE locus by intragenic recombination between segments of hitherto unexpressed pilin DNA sequences (Haas \& Meyer, 1986). Such recombination may be 
mediated by sequences associated with the $73 \mathrm{bp}$ SmaI-ClaI repeat that is located about $65 \mathrm{bp}$ downstream of the complete pilin-coding region and is distributed throughout the chromosome of $N$. gonorrhoeae MS11 ms (Meyer et al., 1984). An identical SmaI-ClaI repeat is found approximately 65 bp downstream of the pilE locus of P9-2. A similar repeat is represented in all pilin clones we have isolated from $N$. gonorrhoeae P9, except where the cloning strategy employed has resulted in the deletion of all, or part, of this region. The $S m a \mathrm{I}-\mathrm{ClaI}$ repeat is also present at two other positions within 2-3 kb of the P9-2 genome, upstream of its pilE locus (Fig. 1) and is represented more than once in several recombinant pilin-elaborating plasmids. The conservation of this sequence close to pilin-related DNA sequences in at least two different gonococcal strains suggests that it plays a crucial role in the mechanism that generates pilus antigenic variation.

Analysis of cloned pilins and their respective gene products indicates that $N$.gonorrhoeae P9 is capable of producing many antigenically distinct pilus types. Pilin clones from strain P9-2 fall into two classes, the monoclonal antibody-binding spectra of which, when superimposed, give the profile obtained with purified pilus preparations from this strain. Since there is apparently only one pilE site in strain P9, the parental P9-2 population used to obtain the clones presumably contained a mixture of cells expressing one or other of only two variant pilin sequences. A similar situation may exist for P9-35 and P9-37, each of which has also given rise to more than one class of cloned pilin gene.

Some reverting $\mathrm{P}^{-}\left(\mathrm{P}^{-} \mathrm{rp}^{+}\right)$derivatives of $N$. gonorrhoeae $\mathrm{MS1} 1_{\mathrm{mk}}$ synthesize pilins that are not assembled into mature pili (Bergstrom et al., 1986; Swanson et al., 1985). Such pilins are either markedly truncated, or are of similar size to pilin from the $\mathrm{P}^{+}$progenitor but contain multiple amino acid substitutions, mainly in the disulphide loop region of the protein (Bergstrom et al., 1986). However, cloned pilins from N. gonorrhoeae P9 are all in the range 18$21 \mathrm{kDa}$, none varying in size from the pilin molecules found in their gonococcal progenitor by more than $1.5 \mathrm{kDa}$. Furthermore, several of the $\mathrm{P} 9$ pilins expressed in $E$. coli, most notably those derived from P9-2, contain epitopes that lie within the hypervariable region of the pilin polypeptide (Virji \& Heckels, 1985). We therefore believe that most, if not all, cloned pilin genes have been derived from $\mathrm{P}^{+} \mathrm{P} 9$ cells. DNA sequencing studies on these variant pilin genes have been carried out to determine the location of the epitopes recognized by the panel of anti-pilus monoclonal antibodies (Nicolson et al., 1987). None of the variants possess premature termination (stop) codons; however, some variants do have TAA stop codons rather that TGA. All of the variant pilin genes with TAA translational stop sequences express pilins that do not react with type-specific monoclonal antibodies that recognize epitopes located in the hypervariable region. It is possible that this subset of pilins could be derived from $\mathrm{P}^{-} \mathrm{rp}^{+}$cells that express defective pilins that are not assembled into pili (Bergstrom et al., 1986).

Part of this work was supported by an MRC project grant to J.R.S. I.J.N. and A.C.F.P. are grateful to the MRC and SERC respectively, for postgraduate scholarships. We are grateful to M. So for supplying us with $E$. coli GC1.

\section{REFERENCES}

Bergstrom, S., Robbins, K., KoOMEy, J. M. \& SWANSON, J. (1986). Piliation control mechanisms in Neisseria gonorrhoeae. Proceedings of the National Academy of Sciences of the United States of America. 83, 3890-3894.

Bolivar, R., Rodriguez, R. L., Greene, P. J., Betlach, M. C., Heynecker, H. L. \& Boyer, H. W. (1977). Construction and characterization of new cloning vehicles. II. A multipurpose cloning system. Gene 2, 95-113.

Brown, M. G. M., Weston, A., SAunders, J. R. \& HUMPHREYS, G. O. (1979). Transformation of Escherichia coli $\mathrm{C} 600$ by plasmid DNA at different phases of growth. FEMS Microbiology Letters 5 , 219-222.
Close, J. C. \& Rodriguez, R. L. (1982). Construction and characterization of the chloramphenicol resistance gene cartridge: a new approach to the transcriptional mapping of extrachromosomal elements. Gene 20, 305-316.

HAAS, R. \& MEYER, T. F. (1986). The repertoire of silent pilus genes in Neisseria gonorrhoeae: evidence for gene conversion. Cell 44, 107-115.

Hagblom, P., Segal, E., Billyard, E. \& So, M. (1985). Intragenic recombination leads to pilus antigenic variation in Neisseria gonorrhoeae. Nature, London 315, 156-158.

Hanahan, D. \& Meselson, M. (1980). Plasmid screening at high colony density. Gene 10, 6367. 
HeCKels, J. E. (1986). Gonococcal antigenic variation and pathogenesis. In Antigenic Variation in Infectious Diseases (Society for General Microbiology Special Publication no. 19), pp. 77-94. Edited by T. H. Birkbeck \& C. W. Penn. Oxford: IRL Press.

Helfman, D. M., Feramisco, J. R., Fiddes, J. C., Thomas, P. G. \& Hughes, S. H. (1984). Immunological screening of cDNA expression libraries. Focus 6 (1), 1-5. BRL Publications.

Humphreys, G. O., Willshaw, G. A. \& ANDERSON, E. S. (1975). A simple method for the preparation of large quantities of pure plasmid DNA. Biochimica et biophysica acta 383, 457-463.

LAMbden, P. R., Robertson, J. N. \& Watt, P. J. (1980). Biological properties of two distinct pilus types produced by isogenic variants of Neisseria gonorrhoeae P9. Journal of Bacteriology 141, 393396.

Lambden, P. R., Heckels, J. E., McBride, H. \& WATT, P. J. (1981). The identification and isolation of novel pilus types produced by variants of Neisseria gonorrhoeae $\mathrm{P9}$ following selection in vivo. FEMS Microbiology Letters 10, 339-341.

Maniatis, T., Frisch, E. F. \& Sambrook, J. (1982). Molecular Cloning : a Laboratory Manual. Cold Spring Harbor, NY: Cold Spring Harbor Laboratory.

Meyer, T. F., Mlawer, N., \& So, M. (1982). Pilus expression in Neisseria gonorrhoeae involves chromosomal rearrangement. Cell 30, 45-52.

Meyer, T. F., Billyard, E., HaAs, R., Storzbach, S. \& So, M. (1984) Pilus genes of Neisseria gonorrhoeae: chromosomal organization and DNA sequence. Proceedings of the National Academy of Sciences of the United States of America 81, 6110-6114.

Nicolson, I. J., Perry, A. C. F., VirJi, M., Heckels, J. E. \& SAUNDERS, J. R. (1987). Localization of antibody-binding sites by sequence analysis of cloned pilin genes from Neisseria gonorrhoeae. Journal of General Microbiology 133 (in the Press).

Pearce, W. A. \& Buchanan, T. M. (1978). Attachment role of gonococcal pili. Journal of Clinical Investigation 61, 931-943.

SAUNDERS, J. R. (1986). The genetic basis of phase and antigenic variation in bacteria. In Antigenic Variation in Infectious Diseases (Society for General Microbiology Special Publication no. 19), pp. 57-76. Edited by T. H. Birkbeck \& C. W. Penn. Oxford: IRL Press.
Segal, E., Billyard, E., So, M., Storzbach, S. \& MEYER, T. F. (1985). Role of chromosomal rearrangement in Neisseria gonorrhoeae pilus phase variation. Cell 40, 293-300.

Segal, E., Hagblom, P., Seifert, H. S. \& So, M. (1986). Antigenic variation of gonococcal pilus involves assembly of separated silent gene segments. Proceedings of the National Academy of Sciences of the United States of America 83, 2177-2181.

SOUTHERN, E. M. (1975). Detection of specific sequences among DNA fragments separated by agarose gel electrophoresis. Journal of Molecular Biology 98, 503-517.

Stern, A., Nickel, P., Meyer, T. F. \& So, M. (1984). Opacity determinants of Neisseria gonorrhoeae: gene expression and chromosomal linkage to the gonococcal pilus gene. Cell 37, 447-456.

SWANSON, J. (1973). Studies of gonococcal infection. IV. Pili: their role in attachment of gonococci to tissue culture cells. Journal of Experimental Medicine 137, 571-589.

Swanson, J., Bergstrom, S., Barrera, O., Robbins, K. \& CoRwIN, D. (1985). Pilus-gonococcal variants. Evidence for multiple forms of piliation control. Journal of Experimental Medicine 162, 729-744.

Towbin, H., Staehelin, T. \& Gordon, J. (1979). Electrophoretic transfer of proteins from acrylamide gels to nitrocellulose sheets: procedure and some applications. Proceedings of the National Academy of Sciences of the United States of America 76, 43504354.

VIRJI, M. \& HeCKELS, J. E. (1983). Antigenic crossreactivity of Neisseria pili: investigations with typeand species-specific monoclonal antibodies. Journal of General Microbiology 129, 2761-2768.

VIRJI, M. \& HeCKeLS, J. E. (1985). Role of anti-pilus antibodies in host defense against gonococcal infection studied with monoclonal anti-pilus antibodies. Infection and Immunity 49, 621-628.

VirJi, M., Heckels, J. E. \& WatT, P. J. (1983). Monoclonal antibodies to gonococcal pili : studies on antigenic determinants on pili from variants of strain P9. Journal of General Microbiology 129, 19651973.

ZaK, K., Diaz, J.-L., Jackson, D. \& Heckels, J. E. (1984). Antigenic variation during infection with Neisseria gonorrhoeae: dilution of antibodies to surface proteins in sera of patients with gonorrhoea. Journal of Infectious Diseases 149, 166-173. 